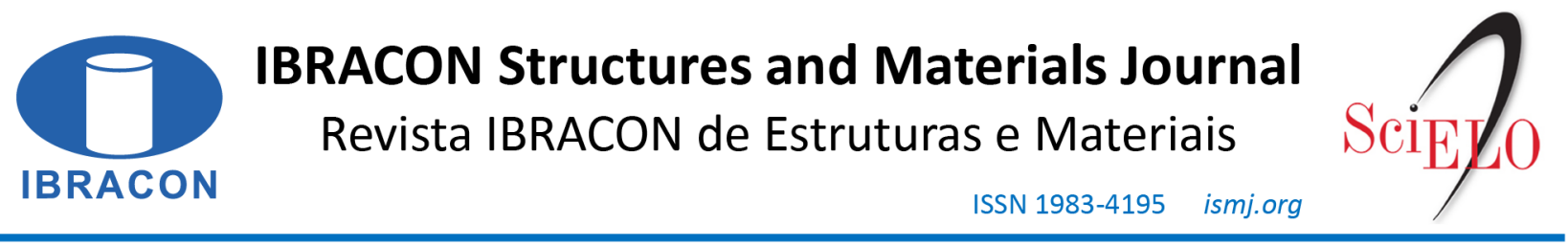

ORIGINAL ARTICLE

\title{
Bending reinforced concrete beams with glass fiber reinforced polymer bars: an experimental analysis
}

\author{
Vigas de concreto armadas à flexão com barras de polímeros reforçados com fibras \\ de vidro: uma análise experimental
}

Tales Viebrantz Fernandes ${ }^{\mathrm{a}}$ (1)

Aline Ribeiro Paliga ${ }^{\text {a }}$ (D)

Charlei Marcelo Paliga ${ }^{\mathrm{b}}$ (ic)

${ }^{a}$ Univesidade Federal de Pelotas - UFPel, Centro de Engenharias, Pelotas, RS, Brasil

${ }^{b}$ Univesidade Federal de Pelotas - UFPel, Faculdade de Arquitetura e Urbanismo, Pelotas, RS, Brasil

Received 15 January 2020

Accepted 07 August 2020

\begin{abstract}
There is a recurring need to construct in places where environmental aggressiveness is very high, such as tidal-splash sites, chemical industries, etc. In these places, steel bars, commonly used for concrete reinforcement, can suffer deterioration, losing cross-sectional area and consequently the resistant capacity. In this regard, Glass Fiber Reinforced Polymers (GFRP) bars can replace steel because of its high strength to harsh environments, low weight and high tensile strength. Thus, this work aimed to compare reinforced concrete beams with steel bars and GFRP bending bars using the procedures indicated in ABNT:NBR 6118 and ACI 440.1R-15, respectively. Experimental three-point flexural tests were performed on six concrete beams, three reinforced with steel bars and three reinforced with GFRP bars. The beams were designed for centered point loads of $23.5 \mathrm{kN}, 37.5 \mathrm{kN}$ and $57 \mathrm{kN}$, and for each load one beam was reinforced in steel and one in GFRP. As main conclusions, it can be said that the beams reinforced with GFRP bars presented greater transverse displacements due to the low modulus of elasticity of this material. In addition, the beams presented rupture loads close to each design load, showing agreement in the recommendations of the two normative documents. Comparing the maximum loads of steel and GFRP beams, ratios of $+9.3 \%,-3.2 \%$ and $-3 \%$ were obtained for beams designed for $23.5 \mathrm{kN}, 37.5 \mathrm{kN}$ and $57 \mathrm{kN}$, respectively. Also, that variations in design loads cause greater variation in the longitudinal reinforcement rate of GFRP bar-beams compared to steel-bar beams.
\end{abstract}

Keywords: GFRP bars, reinforced concrete beams, bending moment design, bending moment test.

Resumo: É recorrente a necessidade da realização de construções em locais onde a agressividade ambiental é muito elevada, como locais propensos a respingos de maré, indústrias químicas, etc. Nesses locais, as barras de aço, comumente utilizadas para a armação do concreto, podem sofrer deterioração, perdendo área da seção transversal e consequentemente a capacidade resistente. Nessa questão, as barras de GFRP (Glass Fiber Reinforced Polymers/polímeros reforçados com fibras de vidro) podem substituir o aço por conta de sua alta resistência a ambientes agressivos, baixo peso e elevada resistência à tração. Assim, esse trabalho teve como objetivo comparar vigas de concreto armadas com barras de aço e com barras de GFRP dimensionadas à flexão através dos procedimentos indicados nas normas ABNT:NBR 6118 e ACI 440.1R-15, respectivamente. Foram realizados ensaios experimentais à flexão por três pontos em seis vigas de concreto, sendo três armadas com barras de aço e três armadas com barras de GFRP. As vigas foram dimensionadas para cargas pontuais centradas de $23,5 \mathrm{kN}, 37,5 \mathrm{kN}$ e $57 \mathrm{kN}$, sendo que para cada carga uma viga foi armada em aço e outra em GFRP. Como principais conclusões, pode-se dizer que as vigas armadas com barras de GFRP apresentaram maiores deslocamentos transversais em virtude do baixo módulo de elasticidade desse material. Ademais, as vigas apresentaram cargas de ruptura próximas para cada carga de dimensionamento, mostrando a concordância nas recomendações dos dois documentos normativos. Se comparadas as cargas máximas das vigas armadas com aço e com GFRP, foram obtidas relações de $+9,3 \%,-3,2 \%$ e $-3 \%$, para as vigas dimensionadas para $23,5 \mathrm{kN}, 37,5 \mathrm{kN}$ e $57 \mathrm{kN}$, respectivamente. Também, que variações nas cargas de

Corresponding author: Charlei Marcelo Paliga. E-mail: charlei.paliga@ufpel.edu.br

Financial support: None.

Conflict of interest: Nothing to declare.

This is an Open Access article distributed under the terms of the Creative Commons Attribution License, which permits unrestricted use, distribution, and reproduction in any medium, provided the original work is properly cited. 
dimensionamento provocam maior variação da taxa de armadura longitudinal das vigas armadas com barras de GFRP quando comparadas com vigas armadas com barras de aço.

Palavras-chave: barras de GFRP, vigas de concreto armado, dimensionamento à flexão, ensaio à flexão.

How to cite: T. V. Fernandes, A. R. Paliga, and C. M. Paliga, "Bending reinforced concrete beams with glass fiber reinforced polymer bars: an experimental analysis," Rev. IBRACON Estrut. Mater., vol. 14, no. 3, e14306, 2021, https://doi.org/10.1590/S1983-41952021000300006

\section{INTRODUCTION}

Technology is constantly and rapidly advancing, and this can be observed in all industries, where new products and materials are constantly made available. In civil construction, however, this process takes longer. When comparing construction with other industries, it becomes obvious that it is lagging behind, since it has long used concrete, wood and steel as its main materials. Yet, analyzing the concrete throughout history, it has not changed significantly since the 1930s [1]. According to Medeiros and Helene [2], this is because concrete has always been an extremely durable material, with no concern for its performance in terms of service life.

According to Bolina et al. [3], a concern with the principles of durability was what started to constitute studies linked to the science of materials used in construction. Although with some delay, the belief that buildings were "forever" started to dissolve, and a restriction on the indiscriminate use of materials in all circumstances began to gain strength. A concern with not only constructing a usable building, but also ensuring that it was a durable product, began to take place.

In Brazil, the first concerns with this issue, in normative terms, emerged in 2003, with the revision of NBR 6118. Then, the classes of environmental aggressiveness were defined, separating the surrounding environment from the structures into four categories, ranked according to their aggressiveness potential against reinforced concrete structures. NBR 6118 was also revised in 2007 and in 2014 and, on both occasions, it still did not quantify the service life of projects for buildings, and this gap was filled in 2013, when the performance standard, which is so debated and put into question [3], came into force.

Pereira and Helene [4] emphasize that the concept of service life is linked to the structural system of the construction, and that when the service life of the structural system ends, the service life of the building also ends. Because this is so important, studies related to the pathological manifestations of reinforced concrete structures are in evidence today.

According to Zhao et al. [5], in engineering, the problem of corrosion of steel bars has increasingly affected the use of reinforced concrete structures and can be classified as one of the main and most important pathological problems. In the 1960s, in the United States, problems related to corrosion began to emerge in road structures treated with deicing salt in colder climates, and in bridges that came into contact with sea salt. Consequently, the steel used in these structures started to present problems related to corrosion [6]. Furthermore, reinforced concrete with steel bars is the most used structural system in Brazil. Therefore, improvements to this system regarding service life and maintenance cost are necessary, mainly in coastal structures, such as bridges, subways, and slope abutments, which are the most critical cases [1].

In addition to issues related to the durability of traditional materials, the increase in the speed of construction has contributed to the development and use of lighter-weight structural materials, with less need for maintenance and less degradation caused by environmental agents [7]. Thus, composite materials based on synthetic fibers and resins are an effective way to solve the problem of corrosion of steel bars.

Today, there are many varieties of composite materials, including SFRP (Steel Fiber Reinforced Polymer), GFRP (Glass Fiber Reinforced Polymer), CFRP (Carbon Fiber Reinforced Polymer), and AFRP (Aramid Fiber Reinforced Polymer), among which GFRP is the cheapest [5].

Thus, according to ACI 440R-96 [6], the main interest of the construction industry in the use of fiber-reinforced polymer bars as reinforcement is linked to their durability, as they do not present corrosion issues, as occurs with reinforced concrete steel. Furthermore, by replacing steel bars, which are conventionally used, with GFRP bars, there is a $25 \%$ reduction in the weight of the bars. This can make structures lighter, reducing the loads needed and optimizing logistics processes and handling of precast concrete parts [8].

Landesmann et al. [9] state that the use of GFRP elements has grown steadily in recent years, as they have become extremely popular in different industries, such as aerospace, automotive, marine, O\&G (oil and gas), and construction. In addition, the authors say that GFRP provides very flexible design solutions, due to its extraordinary flexibility of manufacture, high durability, and structural efficiency (high strength-to-weight ratio). Its use also benefits from increasingly lower production and efficiency costs. As a negative of using GFRP bars to replace steel in concrete beams, Silva [10] points out that beams reinforced with steel bars have greater stiffness, which has been proven through the 
analysis of load $\mathrm{x}$ deflection curves, when compared to beams reinforced with fiber-reinforced polymer bars. This need for improvement justifies studies on the use of these materials in the construction industry.

Although fiber-reinforced polymer bars show high potential for use, currently there is no specific Brazilian standard that regulates the use of this material. Due to this, structural designers have to resort to international standards or practical recommendations from manufacturers. Thus, studies on the use of these bars as reinforcement elements in concrete structures are needed to establish guidelines for their use, which need an abundant number of analyses, studies, and tests. Studies are necessary to obtain a document that can assist projects that aim to use a very promising material.

To better understand a specific use of this material, the present work had the general objective of analyzing the bending behavior of concrete beams reinforced with GFRP bars and comparing them with steel-reinforced beams. To achieve the general objective, some specific objectives were formulated, such as verifying the influence of different design methods (NBR 6118 and ACI 440.1R-15) for bending reinforcement, for the same load levels; analyzing changes in bending behavior of beams when using different standards and different materials, for the same load level; and analyzing the effect of different design loads on the behavior of beams reinforced with steel bars and with GFRP bars in relation to rupture loads and flexural stiffness.

\section{MATERIALS AND EXPERIMENTAL PROGRAM}

Six reinforced concrete beams were designed and tested for different load magnitudes. The point loads applied to the center chosen to perform the flexural design were $23.5 \mathrm{kN}, 37.5 \mathrm{kN}$, and $57 \mathrm{kN}$, in addition to the beam's selfweight. Thus, two beams were designed for each of these loads, one reinforced with steel bars, designed according to NBR 6118 [11], and the other with GFRP bars, designed according to American standard ACI 440.1R-15 [12]. The dimensions of the beams for all situations were set at $14 \times 20 \times 105 \mathrm{~cm}$ (width $\mathrm{x}$ height $\mathrm{x}$ length), and their details followed the recommendations of each standard. Figure 1 presents the schematic drawing of how the experimental tests and the application of the loads were carried out.
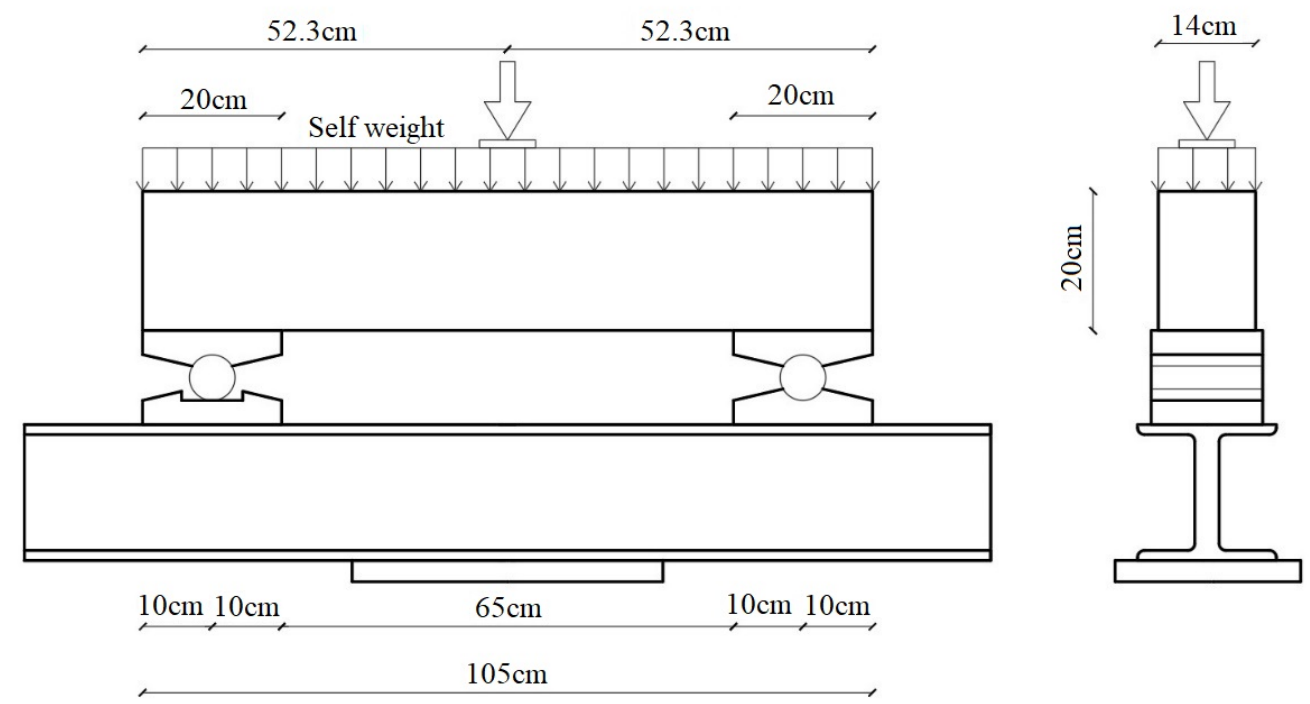

Figure 1. Diagram of the loads of the beams.

The shear design of the beams was determined according to NBR 6118 [11]. Thus, the stirrups on all beams were made of metallic material, CA-60 steel. Since the goal of this work is to analyze flexural behavior, it was ensured, through transverse reinforcement, that the rupture in the beams would occur as desired, that is, due to the normal stress applied to the cross section. Furthermore, since the design of the longitudinal reinforcements resulted in simple reinforcement (only the tensile reinforcement was designed), the upper bars were only used for the assembly of the stirrups. Thus, they were made of steel bars in all six beams.

Table 1 shows the nomenclatures of the beams, which will be used from now on in the text, as well as the design load for each one, and a brief description of their characteristics. 
Table 1. Characteristics of the beams.

\begin{tabular}{ccc}
\hline Abbreviation & Characteristic & Design load (kN) \\
\hline VA23 & Beam reinforced with steel bars & 23.5 \\
\hline VA37 & & 37.5 \\
\hline VA57 & & 57 \\
\hline VV23 & Beam reinforced with GFRP bars & 23.5 \\
\hline VV37 & & 37.5 \\
\hline VV57 & & 57 \\
\hline
\end{tabular}

\subsection{Materials}

For the construction of the six beams, a conventional concrete was produced in the laboratory with characteristic strength to compression, $\mathrm{f}_{\mathrm{ck}}$, of $25 \mathrm{MPa}$, since this is the minimum strength for use in urban environments, and widespread in the construction market, for parts used for structural purposes. To achieve this strength, the dosage method of the Brazilian Portland Cement Association (ABCP) was used. The value of 31.6 MPa was calculated for the average dosage strength, with 4.0 MPa standard deviation. The slump test was 80 to $100 \mathrm{~mm}$, and the water/cement ratio was determined using the dosing methodology (Abrams curve) with a value of 0.51 . At the end, a mass unitary trace was reached, with the following proportions: $1 \mathrm{~kg}$ of cement: $1.98 \mathrm{~kg}$ of sand: $2.31 \mathrm{~kg}$ of gravel, and $0.51 \mathrm{~kg}$ of water.

The aggregate characteristics were determined according to NBR NM 248 [13], NBR NM 53 [14], NBR NM 45 [15], and NBR NM 52 [16], and the results are shown in Table 2. The cement used was CP IV-32 RS, with a specific mass of $2810 \mathrm{~kg} / \mathrm{m}^{3}$, purchased in direct contact with the manufacturer. The water used was supplied by the local water company.

Table 2. Material properties.

\begin{tabular}{ccccc}
\hline & $\begin{array}{c}\text { Maximum characteristic } \\
\text { diameter }(\mathbf{m m})\end{array}$ & Fineness modulus & $\begin{array}{c}\text { Unit mass } \\
\left(\mathbf{k g} / \mathbf{m}^{\mathbf{3}}\right)\end{array}$ & $\begin{array}{c}\text { Specific mass } \\
\left(\mathbf{k g} / \mathbf{m}^{\mathbf{3}}\right)\end{array}$ \\
\hline Gravel of granitic origin & 19 & 4.29 & 1348 & 2655 \\
\hline Quartz sand & 2.36 & 2.59 & - & 2430 \\
\hline
\end{tabular}

To guarantee the technological control of the concrete produced, 18 (three for each beam) $10 \mathrm{x} 20 \mathrm{~cm}$ (diameter $\mathrm{x}$ height) cylindrical specimens were cast. They were tested by compression at 28 days, with an average strength value of $31.13 \mathrm{MPa}$, which is close to the average dosage strength of 31.6 MPa. This value demonstrates the good quality of the concrete.

\subsection{Design and reinforcement of the beams}

The material of the longitudinal reinforcement of beams reinforced against tension with steel bars, VA23, VA37 and VA57, was CA-50 steel. The design and detailing were carried out according to NBR 6118 [11]. The nominal coverage of the reinforcement was $25 \mathrm{~mm}$, going from the face of the beam to the face of the reinforcement. Plastic spacers were used to ensure this coverage.

The flexural design and detailing of the beams reinforced with GFRP bars, VV23, VV37, and VV57, was carried out according to the American standard ACI 440.1R-15 [12] - Guide for the Design and Construction of Concrete Reinforced with FRP Bars. The properties of the GFRP bars were provided by the manufacturer and can be seen in Table 3. Figure 2 shows the GFRP bars, with diameters of $6 \mathrm{~mm}, 12 \mathrm{~mm}$ and $25 \mathrm{~mm}$. 
Table 3. Commercial diameters of the GFRP bars, and their properties.

\begin{tabular}{|c|c|c|c|c|c|c|c|c|c|}
\hline \multirow[b]{2}{*}{ Properties } & & \multicolumn{8}{|c|}{ Standard diameters $(\mathrm{mm})$} \\
\hline & & 6 & 9 & 12 & 14 & 18 & 20 & 25 & 32 \\
\hline $\begin{array}{l}\text { Nominal tensile } \\
\text { strength }\end{array}$ & $\mathrm{MPa}$ & 1070 & 1047 & 989 & 953 & 903 & 876 & 831 & 727 \\
\hline Tensile force & $\mathrm{kN}$ & 24.53 & 53.96 & 91.23 & 119.68 & 187.37 & 224.65 & 333.54 & 420.85 \\
\hline Poisson's ratio & - & 0.25 & 0.21 & 0.26 & 0.25 & 0.25 & 0.25 & 0.28 & 0.26 \\
\hline Young's modulus & $\mathrm{GPa}$ & 48 & 48 & 48 & 48 & 47 & 47 & 46 & 46 \\
\hline $\begin{array}{c}\text { Nominal compressive } \\
\text { stress }\end{array}$ & $\mathrm{MPa}$ & 553 & 541 & 494 & 483 & 514 & 516 & 505 & 493 \\
\hline Elongation & $\%$ & 2.12 & 2.11 & 2.05 & 2.03 & 2.08 & 2.1 & 2.07 & 2.15 \\
\hline Nominal shear stress & MPa & 210 & 210 & 210 & 210 & 204 & 204 & 200 & 200 \\
\hline
\end{tabular}

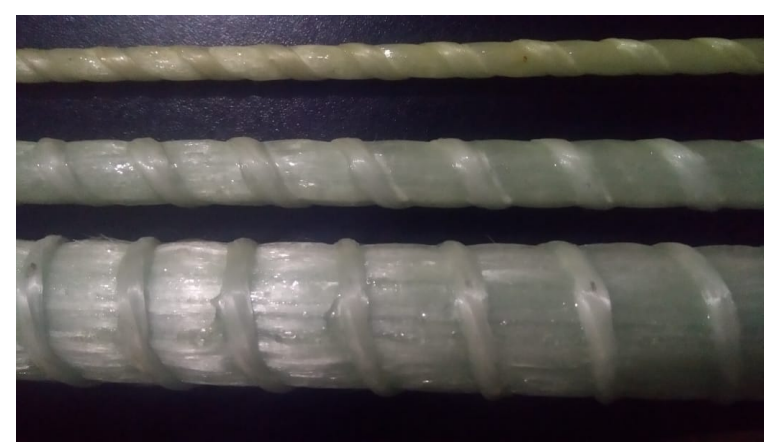

Figure 2. Ribbed GFRP bars.

Table 4 presents the areas of steel and GFRP calculated to absorb the tensile stress caused by the bending of the beams, and Figure 3 brings the details of the beams. Figure 4 shows the completed reinforcement of beams VV37 and VA37. After concreting the beams, they were left in an appropriate place in the laboratory, with wet curing by sprinkling water during the first days, and then they were ruptured after 28 days.

Table 4. Reinforcement area found in the design stage.

Abbreviation
Designed area $\left(\mathrm{cm}^{2}\right)$
Adopted solution

Existing area $\left(\mathrm{cm}^{2}\right)$

\begin{tabular}{|c|c|c|c|c|}
\hline VA23 & \multirow{2}{*}{23.5} & 1.04 & $2 ø 8$ & 1.01 \\
\hline VV23 & & 0.84 & $3 ø 6$ & 0.85 \\
\hline VA37 & \multirow{2}{*}{37.5} & 1.87 & $2 ø 10+1 ø 6.3$ & 1.88 \\
\hline VV37 & & 2.25 & $2 ø 12$ & 2.26 \\
\hline VA57 & \multirow{2}{*}{57} & 2.87 & $2 ø 12.5+1 \varnothing 8$ & 2.95 \\
\hline VV57 & & 9.48 & $2 ø 25$ & 9.82 \\
\hline
\end{tabular}




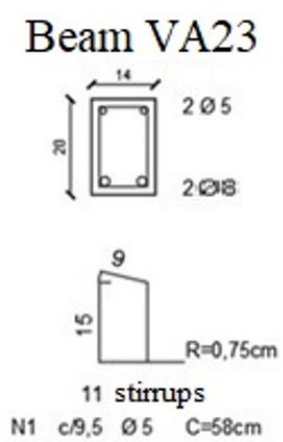

\section{Beam VV37}
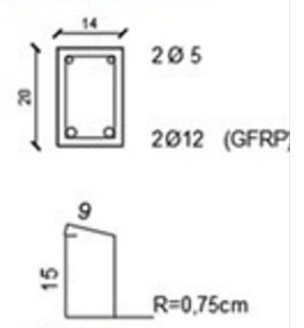

11 stirrups

N2 $\quad 09,5 \quad 05 \quad \mathrm{C}=58 \mathrm{~cm}$
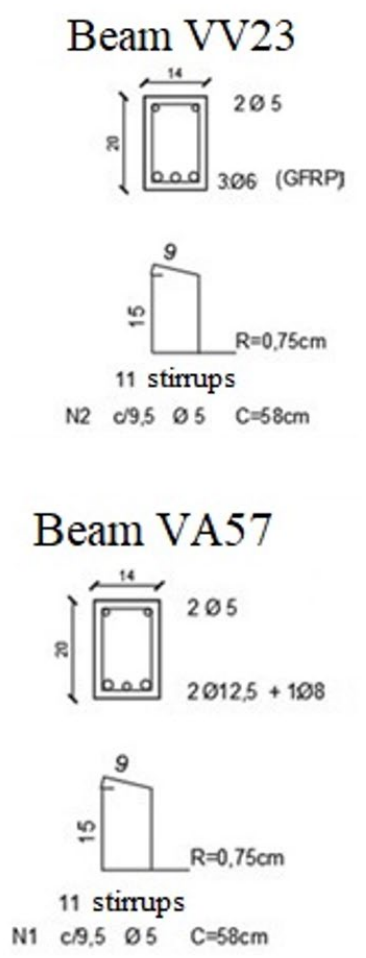
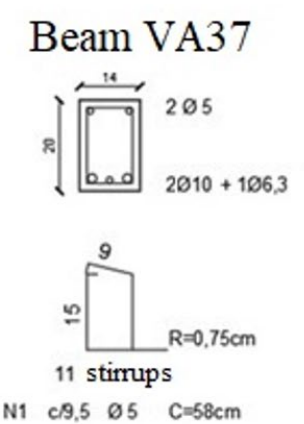

Beam VV57
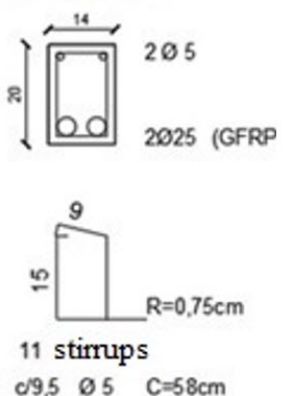

Figure 3. Transversal detailing of the tested beams.

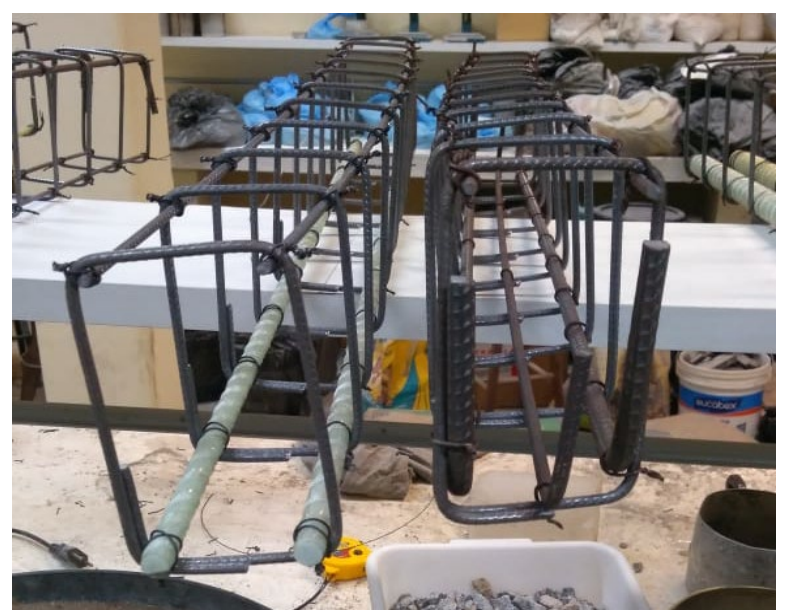

Figure 4. Reinforcement of beams VV37 and VA37.

\section{RESULTS AND DISCUSSION}

This section presents the results obtained for the beams during the experimental tests performed at 28 days.

\subsection{Beams designed for $23.5 \mathrm{kN}$ (VA23 and VV23)}

The load $x$ displacement curves obtained in the tests of beams VA23 and VV23 are shown in Figure 5. With a load of approximately $20 \mathrm{kN}$, beam VA23 began to crack, after that, appeared the next two cracks with loads of $30 \mathrm{kN}$ and $45 \mathrm{kN}$, caused by bending. After that, the cracking increased until the reinforcement began to yield, with a load of approximately $60 \mathrm{kN}$. The maximum load supported by this beam was $76.32 \mathrm{kN}$, and the corresponding displacement was $8.62 \mathrm{~mm}$. This rupture happened smoothly, since steel was in plastic regime. 
For beam VV23, cracks began to appear with a load of $24.5 \mathrm{kN}$, as can be clearly seen in Figure 5. The cracks were limited to the lower part of the beam, in the direction of the neutral line, presenting a more visible opening close to the bottom endpoint. Flexural cracks can be seen in Figure 6. As the load increased, the beam ruptured abruptly, which is consistent with the brittle linear behavior of the GFRP bars. The mode of failure of the concrete beam occurred due to the tensile rupture of the GFRP bars, as expected, and according to the calculation for this beam, in which the bars were designed considering their tensile strength. This mode of failure of the concrete beam is the one that uses the GFRP bars to their maximum, however, it is the form that requires the greatest care, due to the brittle form of rupture. The maximum load supported by the beam was $69.8 \mathrm{kN}$ for an $11.3 \mathrm{~mm}$ deflection. At that moment, there was a rupture of one of the GFRP bars, shown in the graph in Figure 5 by the abrupt drop in the load to maintain the displacement rate constant. In addition, it is possible to observe the rupture of the other two bars in the displacements around $13.2 \mathrm{~mm}$ and $14 \mathrm{~mm}$. Figure 7 shows the ruptured bars, through the crack that caused the beam to break.

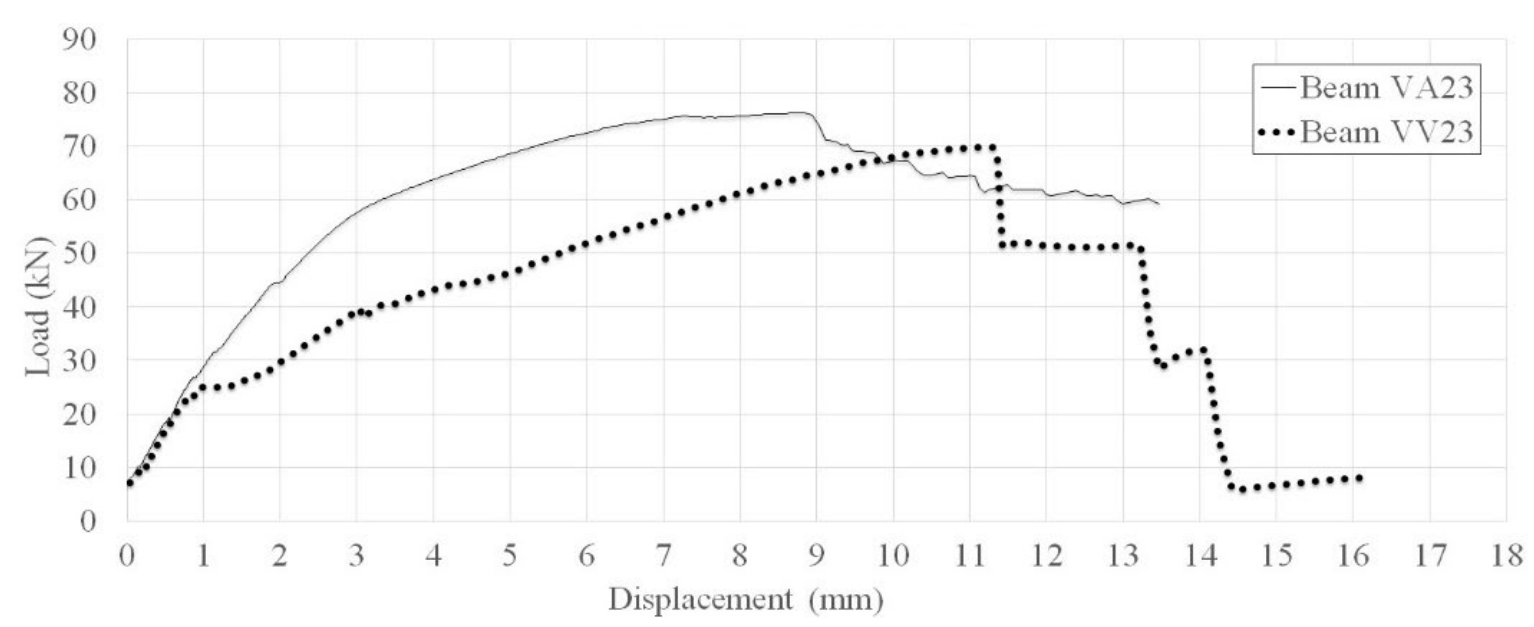

Figure 5. Load vs displacement curves of the $23.5 \mathrm{kN}$ beams.

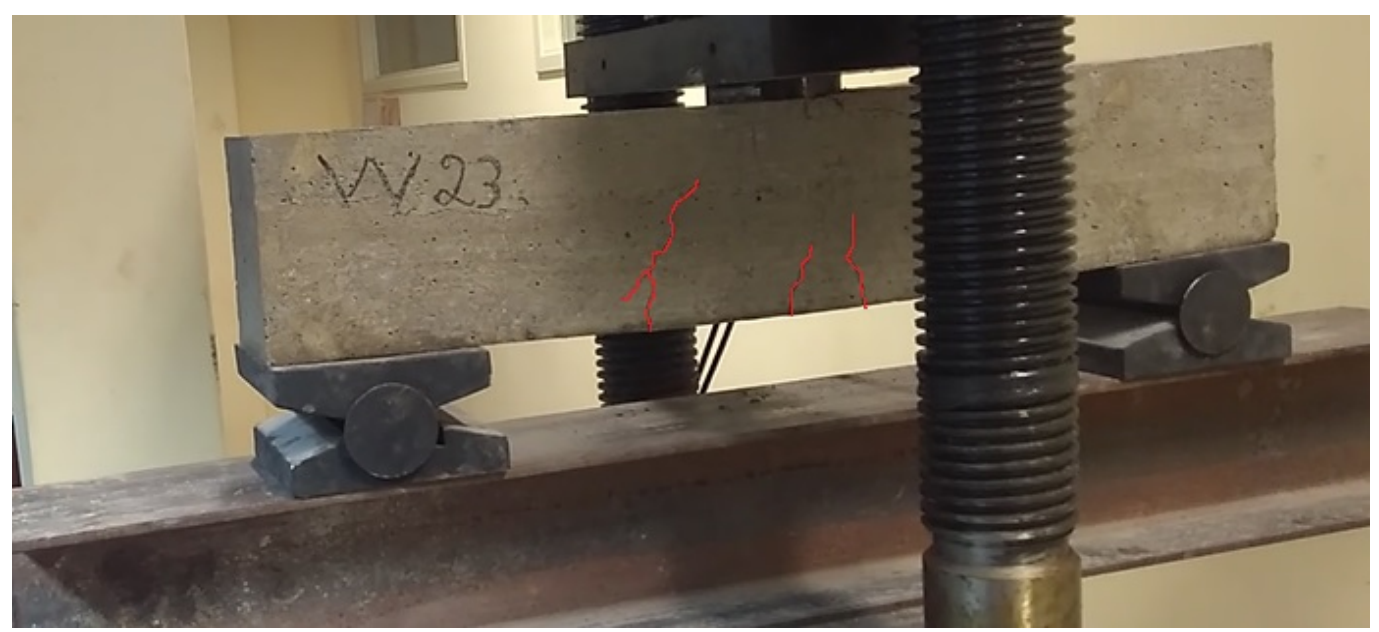

Figure 6. Cracks observed in the VV23 beam. 


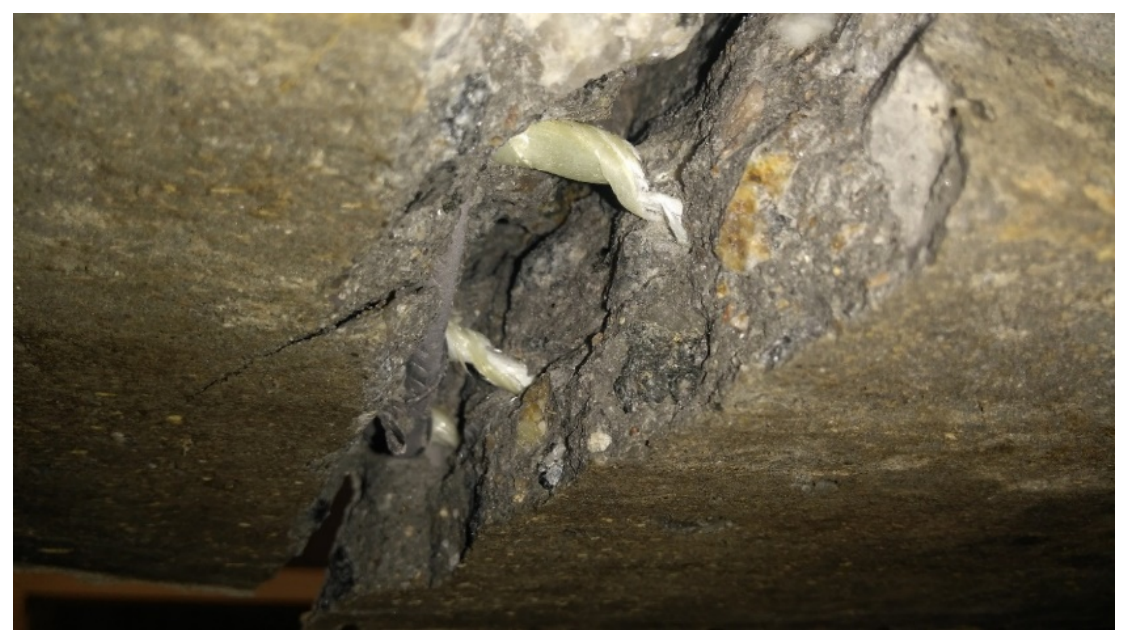

Figure 7. Rupture of the GFRP bars of the VV23.

Analyzing the graphs presented in Figure 5, the steel-reinforced beam presented a greater maximum load and displacement corresponding to the smaller load when compared to the beam reinforced with GFRP. In percentage terms, beam VA23 supported a load 9.3\% higher than beam VV23, that is, $76.32 \mathrm{kN}$ and $69.8 \mathrm{kN}$, respectively. In addition, the GFRP beam had a displacement $26 \%$ greater than the beam reinforced with steel against tension, at its maximum load. Also, it should be noted that until they started to crack, the two beams presented the same stiffness. This behavior can be explained by the fact that the tensile stress is absorbed by the concrete, with the collaboration of the tension reinforcement starting after the cracking. After that, for the same load level, beam VV23 showed greater displacements, a fact that can be easily explained by the lower longitudinal elastic modulus of the GFRP bars when compared to the same property in steel, $48 \mathrm{GPa}$ and $210 \mathrm{GPa}$, respectively. In addition, after cracking, the behavior of the GFRPreinforced beam is practically linear until it reaches its maximum load. This behavior is given by the linearity of the stress $\mathrm{x}$ strain curve of the bars made of composite materials.

Another extremely important fact that should be noted regarding the different behaviors of the beams reinforced with metallic material or with material based on fiber-reinforced polymer is that after reaching its maximum load capacity, beams with metallic material still managed to withstand a quite considerable load level, which was not observed for the GFRP beams. This difference in behavior can be explained by one material being ductile (steel) and the other brittle (GFRP).

\subsection{Beams designed for $37.5 \mathrm{kN}$ (VA37 and VV37)}

The load $\mathrm{x}$ displacement curves obtained during the tests with beams VA37 and VV37 are shown in Figure 8.

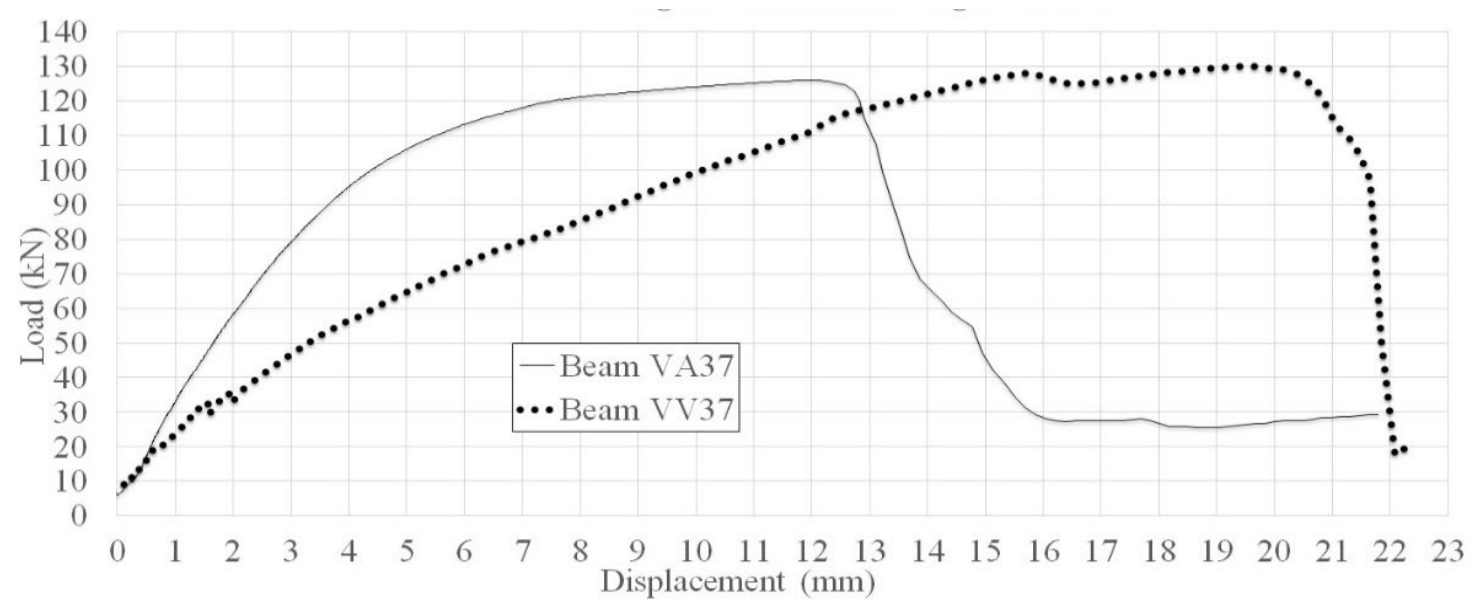

Figure 8. Load vs displacement curves of the $37.5 \mathrm{kN}$ beams. 
The maximum load supported by the VA37 was $126 \mathrm{kN}$, for a corresponding deflection of $11.8 \mathrm{~mm}$. The cracks started to be visible with a load of approximately $52 \mathrm{kN}$. However, at a load close to $20 \mathrm{kN}$, there was a change in the slope of the load $\mathrm{x}$ displacement curve shown in Figure 8, possibly indicating the opening of the first crack within the beam. The rupture occurred smoothly, with steel in the plastic regime, as expected.

The maximum load supported by beam VV37 was $130.13 \mathrm{kN}$, with a corresponding deflection of $19.6 \mathrm{~mm}$. Figure 9 shows the cracks that appeared during the test, the first of which appeared with a load of approximately $20 \mathrm{kN}$, as can be seen in Figure 8 through the disturbance in the load so the press could adjust and apply the displacement at a constant rate again. Other cracks occur near $35 \mathrm{kN}$, when the GFRP bars become more important in absorbing the tensile stress generated by the bending of the beam. It should be noted that up to a load of approximately $130 \mathrm{kN}$, the beam's behavior was almost linear, suggesting the actual collaboration of the bars for the absorption of stress. The rupture occurred abruptly, indicated by the drop in load applied to the beam for a displacement of about of $21 \mathrm{~mm}$. Before the rupture, there was "crackling" due to concrete crushing; it is believed that the concrete reached its compression limit when the beam displacements were between 16 and $20 \mathrm{~mm}$, approximately.

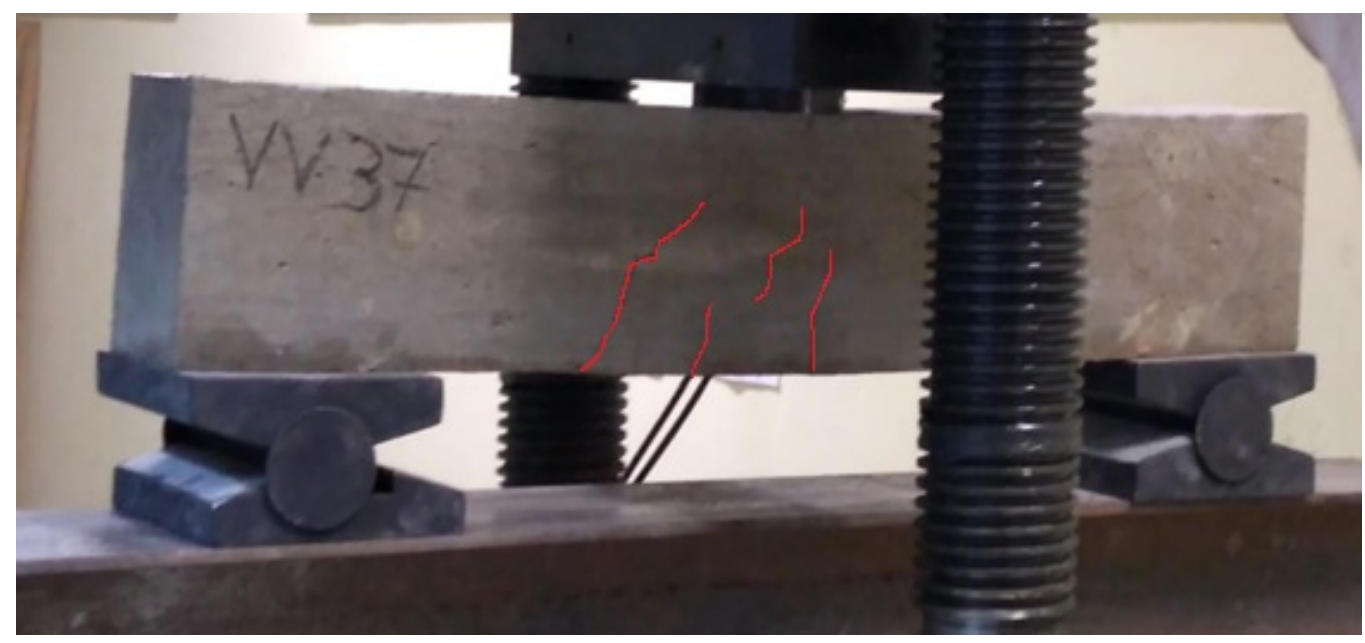

Figure 9. Cracks observed in beam VV37.

The failure of the beam reinforced with GFRP bars occurred by concrete crushing, without the bars breaking due to tension. It is noteworthy that this was the mode of failure obtained when designing the cross-sectional area of the GFRP bars, corroborating the results observed in the test, with concrete crushing without reaching the ultimate tensile strength of the bars.

When analyzing Figure 8, which shows the overlapped curves of the steel-reinforced beam, VA37, and the GFRPreinforced beam, VV37, it can be observed that the GFRP beam presented a higher load, about 3\% greater. Also, the deflection found was $64 \%$ higher for the maximum load of the GFRP beam, when compared to the displacement of the maximum load of the steel beam. The same behavior was obtained for the $23.5 \mathrm{kN}$ beams, due to the elastic modulus of the GFRP bars being lower than that of steel bars.

Again, these tests showed that the two beams behave similarly until the concrete begins to crack. After this, the tensile reinforcement starts to collaborate effectively for the absorption of stress, affecting and differentiating the behavior of the two beams according to the different behaviors of the steel bars and the GFRP bars.

\subsection{Beams designed for $57 \mathrm{kN}$ (VA57 and VV57)}

The VA57 beam supported a load of $143.8 \mathrm{kN}$, with a corresponding deflection of $18.6 \mathrm{~mm}$. Figure 10 shows the cracks that caused the beam to rupture, which occurred due to flexural stresses. Figure 11 presents the load $x$ displacement curves of the beams designed for the $57 \mathrm{kN}$ load. 


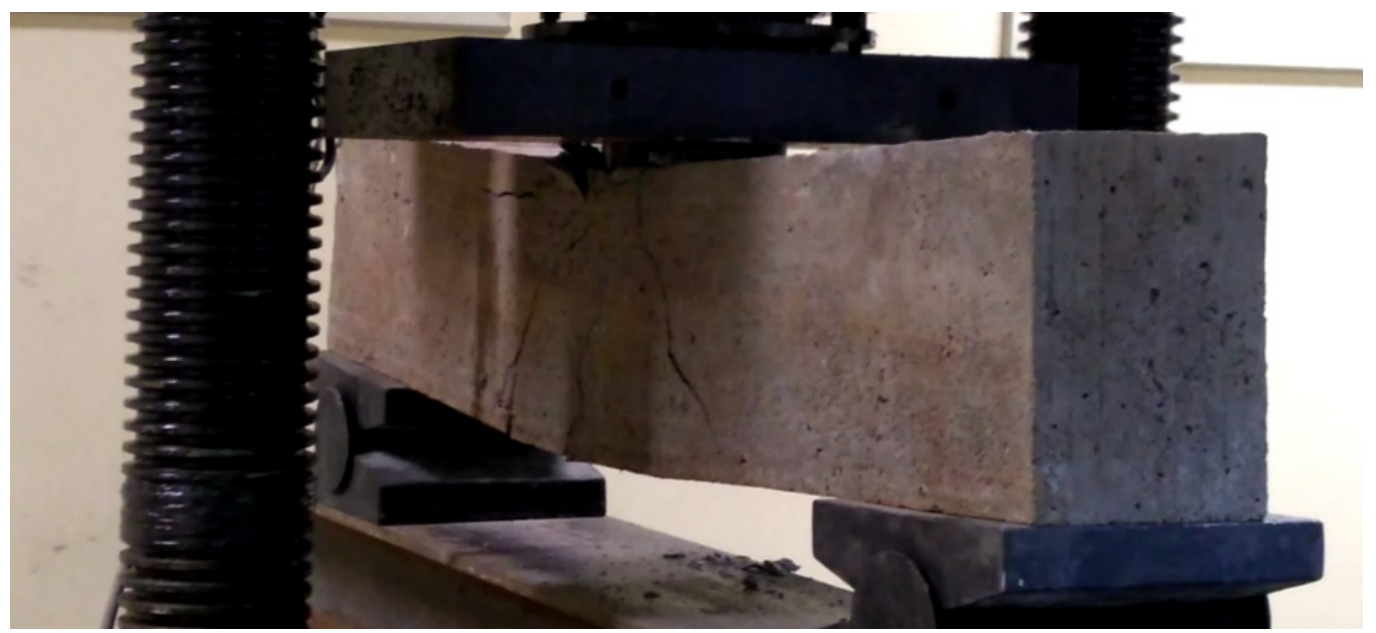

Figure 10. Rupture of beam VA57.

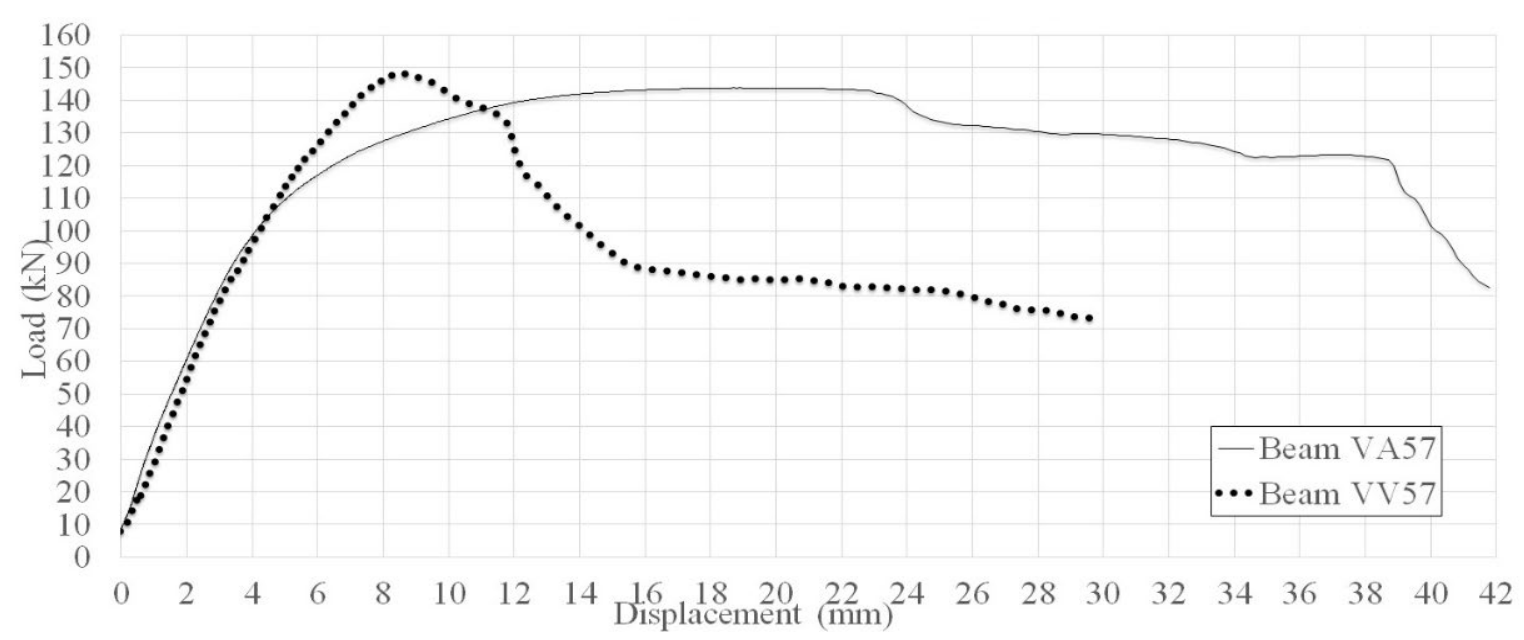

Figure 11. Load vs displacement curves of the $57 \mathrm{kN}$ beams.

An analysis of the VA57 beam shows that it behaved linearly up to a load of approximately $100 \mathrm{kN}$, indicating the effective collaboration of the tensile reinforcement, possibly working in the elastic regime. After this load level, it is believed that the steel entered its plastic phase, that is, it yielded, absorbing stresses up to a displacement level of 23 $\mathrm{mm}$, when it is believed that concrete crushing began. It is noteworthy that this beam was designed with a position relative to the neutral line close to 0.45 (domain 3 ), which indicates failure of the element with concrete crushing and steel in the plastic regime. Failure said to be ductile with intense cracking and compressed concrete reaching its resistant capacity, which meets the rupture mode found in the test.

The VV57 beam supported a maximum load of $148.3 \mathrm{kN}$ for an $8.5 \mathrm{~mm}$ deflection. The graph in Figure 11 shows the actual collaboration of the GFRP bars for beam strength, due to the linear behavior of the load x displacement curve of VV57 until the maximum load $(148.3 \mathrm{kN})$. This behavior is typical of fiber-reinforced polymer bars. After the maximum load, the press was forced to decrease the load applied to the beam so that it could maintain a constant displacement rate, due to the loss of stiffness caused by the start of concrete crushing, going up to a displacement of about $16 \mathrm{~mm}$.

As an important information, it should be said that the GFRP area for the $57 \mathrm{kN}$ load was designed by predicting beam failure by concrete crushing with underutilization of the resistant capacity of the bars, which can be seen in Figure 12, which translates the behavior expected in the test. The same Figure 12a shows how the excess compression deformed the upper reinforcement, while the lower reinforcement, shown in Figure 12b, did not reach its maximum capacity. 

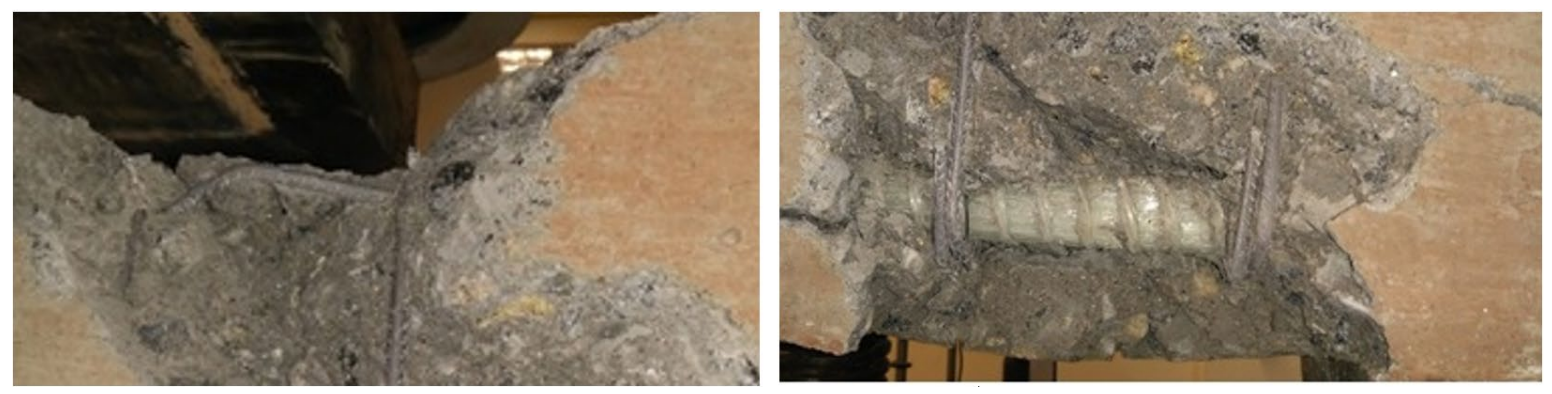

Figure 12. a Crushed concrete. b. Intact GFRP bars.

The load supported by beam VV57 is about 3\% higher than beam VA57. Still, its vertical displacement was much lower than the displacement of the steel beam, about $119 \%$, when compared to the displacements in the maximum loads supported by the beams. This behavior is different from the other results presented here. This was due to the reinforcement rate of the GFRP beam $\left(9.82 \mathrm{~cm}^{2}\right)$ being much higher than that of the steel beam $\left(2.95 \mathrm{~cm}^{2}\right)$, thus compensating for the lower elastic modulus of the fiber-reinforced polymer bars. In addition, as shown in the graphs in Figure 11, the two beams behaved very similarly until a load level close to $100 \mathrm{kN}$. This is explained by the high GFRP reinforcement rate in relation to the steel rate, approximately 3.3 times higher, which made these beams behave differently than the other four beams. After this load, the beams start to behave differently, because the steel yields, providing greater ductility to the beam, unlike the GFRP bars, which have elastic-linear behavior. Through these curves, it becomes clear how the properties of the materials (steel/GFRP) interfere in the behavior of the beams, giving them more or less ductility.

\subsection{Comparison between steel and GFRP bars}

Table 5 shows the tensile reinforcement area used in each of the beams. Most of the beams designed with GFRP had a larger cross-sectional area when compared to the corresponding steel beams. This was expected, due to the elastic modulus of the GFRP bars being lower than the longitudinal elastic modulus of the steel bars. However, it should be noted that the bars were not ruptured in beams VV37 and VV57, thus, their resistant capacity was not reached. In beam VV23, however, failure occurred due to the rupture of the GFRP bars due to tensile strength, with the three failure modes obtained in the tests following those used in the design.

Table 5. Comparison between flexural reinforcement areas.

Abbreviation Flexural reinforcement Ratio between the area $\left(\mathrm{cm}^{2}\right) \quad$ VV/VA areas $(\%)$
Ratio between Design load/Reinforcement $\operatorname{area}\left(\mathrm{kN} / \mathrm{cm}^{2}\right)$

\begin{tabular}{cccc}
\hline VA23 & 1.01 & $84 \%$ & 23.27 \\
\hline VV23 & 0.85 & & 27.65 \\
\hline VA37 & 1.88 & $120 \%$ & 19.95 \\
\hline VV37 & 2.26 & & 16.59 \\
\hline VA57 & 2.95 & $333 \%$ & 19.32 \\
\hline VV57 & 9.82 & 5.80 \\
\hline
\end{tabular}

Beam VV57 presented an area 3.33 times greater when compared with the corresponding steel beam, VA57. However, it did not present a much higher ultimate load, only 1.06 times greater, because the final strength in these 
beams was limited by the compressive strength of the concrete, with underutilization of the resistant capacity of the bars.

In addition, the beam that presented the best design load/reinforcement area ratio, that is, the most efficient design, was VV23, which was designed for the tensile rupture of the GFRP bars, and reached what was expected, with the total use of its resistant capacity. However, it should be noted that these results have to do with the ultimate flexural limit when the resistant capacity of the element is exhausted.

Regarding issues related to deformations, which must be sufficiently small when in service loads, under penalty of causing problems for the use of the buildings, VV23 had a worse performance than VA23 after moving to stage II. For a load of $30 \mathrm{kN}$, the steel-reinforced beams presented a displacement of $1.05 \mathrm{~mm}$, while the GFRP-reinforced beams had a $94 \%$ greater displacement, of $2.04 \mathrm{~mm}$. After a load increase, this loss of performance became more pronounced, with displacements $101 \%$ and $138 \%$ greater than the steel-reinforced beam for loads of $40 \mathrm{kN}$ and $50 \mathrm{kN}$, respectively. Thus, the lower post-cracking stiffness presented by the VV23 beam in comparison to the corresponding steelreinforced beam should be noted. This is due to the longitudinal elastic modulus of the GFRP being approximately $23 \%$ of the longitudinal elastic modulus of steel, which is a negative point of using this material. This issue can be compensated with a larger cross section, for example.

The beams reinforced against tension with steel bars did not present great differences between design load/reinforcement area ratio, with an average ratio of $20.85 \mathrm{kN} / \mathrm{cm}^{2}$, standard deviation of $2.12 \mathrm{kN} / \mathrm{cm}^{2}$, and coefficient of variation related to these values of $10.2 \%$. The GFRP-reinforced beams, on the other hand, had an average ratio of $16.68 \mathrm{kN} / \mathrm{cm}^{2}$, standard deviation of $10.93 \mathrm{kN} / \mathrm{cm}^{2}$, and coefficient of variation of $65.5 \%$. Thus, variations in design loads induce more significant variations in the reinforcement areas of GFRP bars than in steel bars.

\subsection{Steel-reinforced beams}

Figure 13 shows the load $\mathrm{x}$ displacement curves of the beams that used steel to resist the tensile stresses caused by the bending moment. All beams had curves with a very similar shape, with changes in the strength and also the stiffness scales, mainly for beam VA23 when compared to beams VA37 and VA57. This is the expected behavior for beams designed to have good ductility, as recommended by standards for design. In addition, there is a change in stiffness of the beams when they enter stage III (reinforcement yield), especially beams VA37 and VA57 (load greater than 110 $\mathrm{kN}$ ), where VA57 had less deformation compared to VA37 due to higher reinforcement rate.

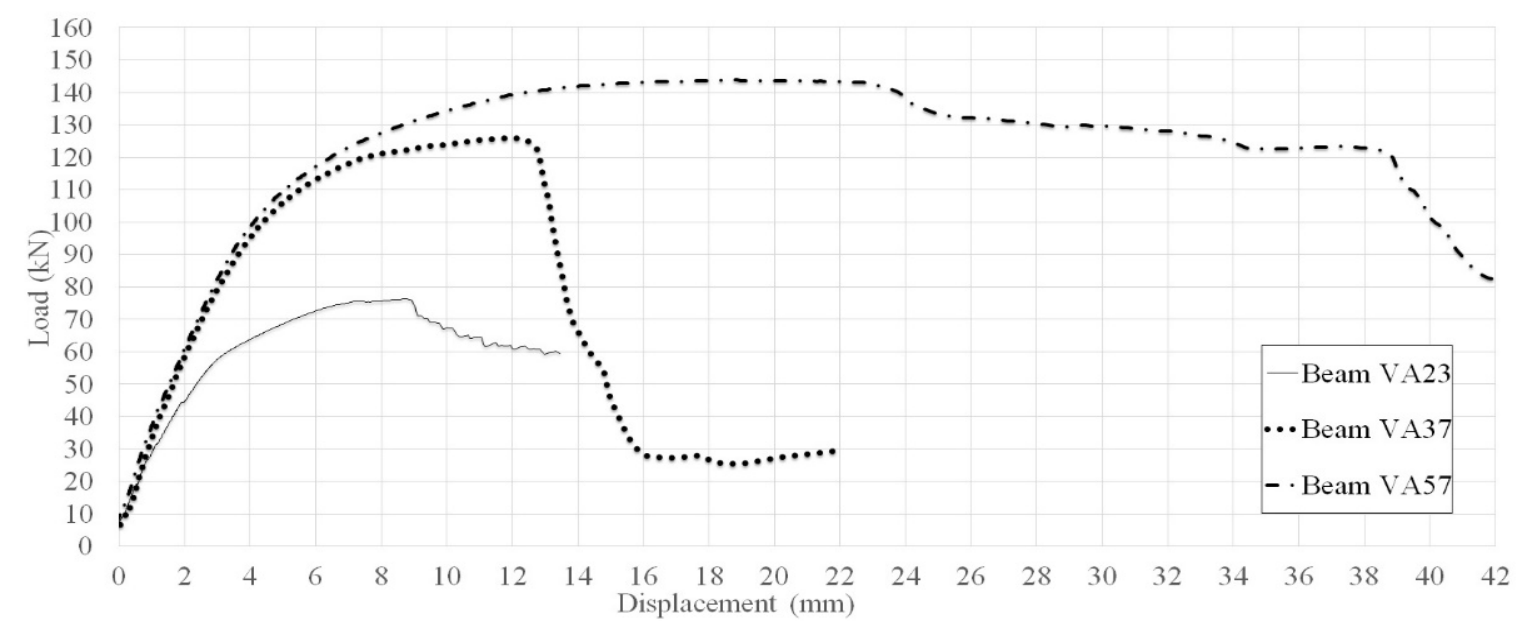

Figure 13. Load vs displacement curves - Beams reinforced with steel.

Also, there was no major increase in strength between beams VA37 and VA57, in which the latter had a reinforcement rate 57\% higher, with load capacity only $14 \%$ higher than VA37. In these cases, the strengths of the beams were limited by the compressive strength of the concrete. Thus, the bars that resisted bending, at the bottom of the beams, did not significantly increase their final strengths. For that, it would be necessary to increase the compressive strength of the concrete or the cross section of the beam. 


\subsection{GFRP-reinforced beams}

Figure 14 shows that the GFRP beams had a sudden drop in strength after reaching their maximum load. This was due to the brittle behavior of the concrete and GFRP that were used. Beams VV23 and VV37 completely lost their load capacities after reaching their maximum load, even though they have different modes of failure, with the first, for beam VV23, caused by the tensile rupture of the bars, and the second, for beam VV37, by concrete crushing. It is important to note that the modes of failure obtained with the tests faithfully followed the modes of failure detailed in the design process.

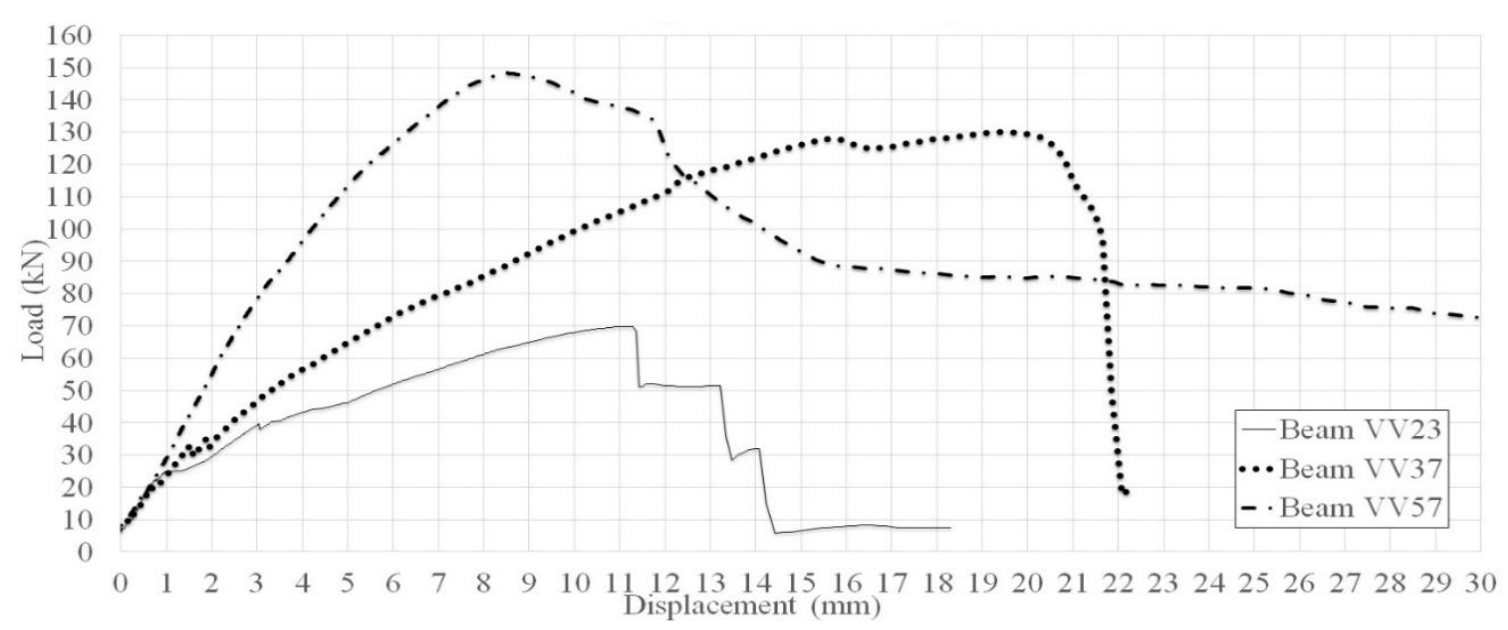

Figure 14. Load vs displacement curves - Beams reinforced with GFRP.

The behavior of beam VV57 was not compatible with the two other GFRP-reinforced beams. This was because the VV57 beam had a much higher tensile reinforcement area than the others. While beam VV57 had a tensile reinforcement area 4.35 times greater than that of VV37, this difference was even greater compared to VV23, where it was 11.55 times greater. Thus, even after the concrete crushing, the beam still retained a rate of load capacity. However, this higher reinforcement rate did not mean differences of the same magnitude in relation to rupture loads, with the maximum load of VV57 being 2.12 times higher than the load of VV23, and 1.14 times higher than the maximum load of VV37. This increase in area by 4.35 times, but only 1.14 times of maximum load, when compared to beams VV37 and VV57, is a clear indication that their mode of failure was given by the limitation of concrete compressive strength.

\subsection{Beams reinforced with steel and GFRP bars}

Figure 15 shows that beam VV57 behaved similarly to the beams reinforced with steel bars, VA37 and VA57, mainly until the steel bars yielded. After that, VV57 presented greater stiffness in relation to the other two beams until reaching its maximum load capacity. This is due to the reinforcement area of this beam being much higher than the reinforcement of beams VA37 and VA57, that is, 5.22 and 3.33 times higher, respectively, thus compensating for its low longitudinal elastic modulus. However, beam VV57 had significantly lower deflection than beams reinforced with steel bars when comparing the maximum loads, which is a negative factor, due to the greater fragility of this material. 


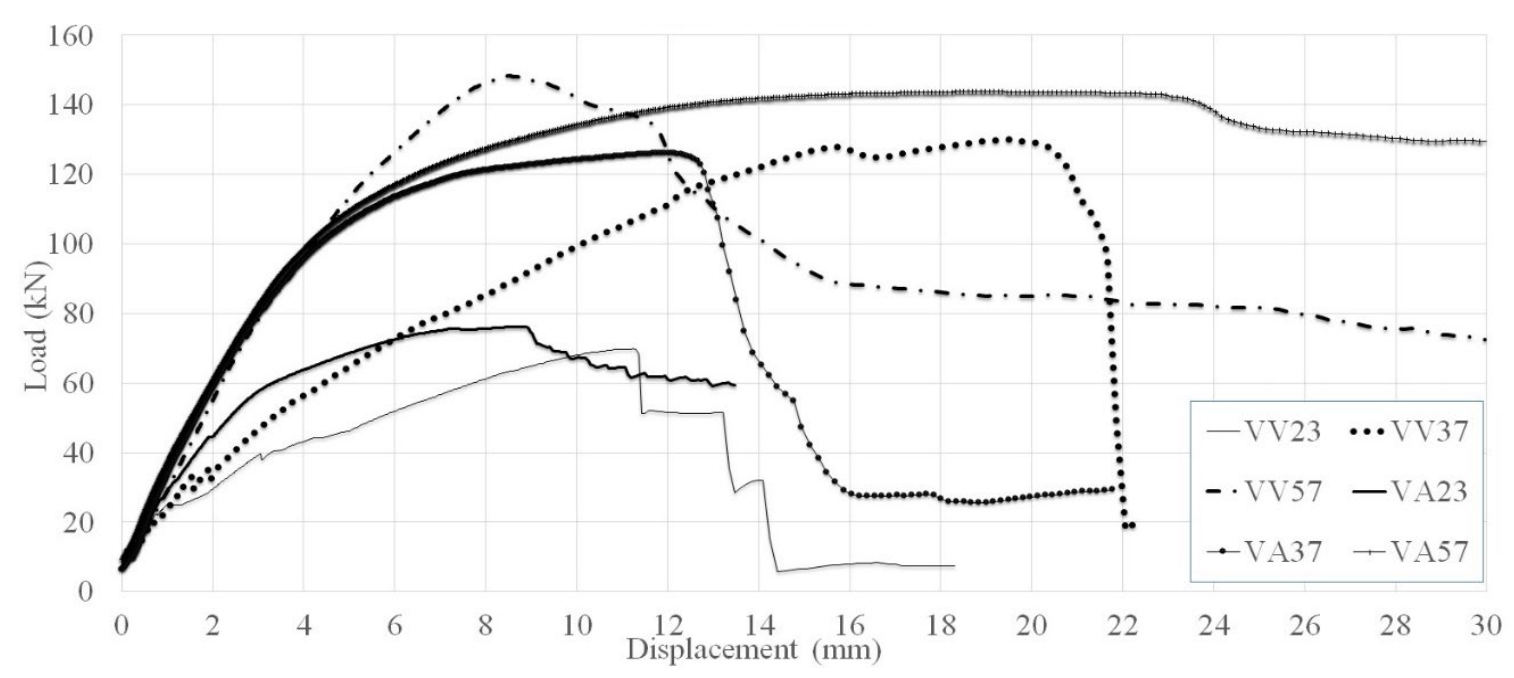

Figure 15. Load vs displacement curves for all beams.

\section{CONCLUSIONS}

The present work aimed to compare beams reinforced with GFRP and reinforced with steel, which followed different standards documents and had different load levels. After reaching and presenting the results of this experimental research, some conclusions can be drawn.

The beams reinforced with GFRP bars had greater displacements when compared to those reinforced with steel, due to the elastic modulus of this material being almost $80 \%$ lower. Although the rupture occurs abruptly, which is characteristic of brittle materials, the displacement of the beam is excessive before failure. This displacement can serve as a warning for possible design flaws before the collapse, because after the beam reaches its maximum load, its strength drops abruptly, leading to its collapse. However, it is important to highlight here that the beams were designed only for the limit state of depletion of the resistant capacity of the materials, both in terms of bending and shear. Thus, for a confirmation of what was said above, an analysis must be carried out during the project regarding the service limit state related to excessive deformations.

Although the deformations of the GFRP beams were quite high, due to the low elastic modulus of this material, this behavior can be mitigated by a higher flexural reinforcement rate. The results of beam VV57 can be used as an example. This beam had a higher maximum load (about 3\%), and the displacement related to the maximum load was about 50\% lower when compared to VA57. However, this behavior can make the production of the piece quite expensive due to the high cost of GFRP bars, when compared to steel. Also, care must be taken when designing a concrete element with low displacement in the ultimate limit state, since displacement is an early warning for failure.

The final strength of the beam is sensitive to the concrete compressive strength and its cross-sectional dimensions, because of the modes of failure linked to concrete crushing. For the safer design of beams reinforced with GFRP bars, it is important to pay greater attention to the form of failure and seek to ensure the greatest possible ductility. This situation occurs when there is a high deformation at the compressed edge at the moment of the rupture simultaneously with a high tensile deformation in the bars, resulting in a large curvature.

The American standard allows that both the form of rupture dominated by tensile and compression can occur, although it recommends that the concrete crushing occurs before the FRP rupture, this being the failure mode of the VV37, with concrete crushing and possible great deformation in the GFRP bars, even if its strength has not been reached. In the VV57 case, there was a failure of the beam by concrete crushing before mobilizing a significant tensile deformation in th GFRP bars, indicated by the low ductility of the beam compared to the respective beam reinforced with steel. It is noteworthy that this was the only beam reinforced with GFRP that presented a lower displacement than its respective reinforced steel beam when the maximum load was reached.

However, this form of design may not be the most efficient. An example of this is beam VV23, in which there was tensile rupture of the GFRP bars, indicating they had reached their limits of use. Furthermore, the rate of flexural reinforcement was lower in the beams reinforced with GFRP bars compared to the beams reinforced with steel bars (VA23). Also, there were no significant differences in the maximum loads between these two beams, with a maximum load/design load ratio of 3.25 and 2.97 for beams VA23 and VV23, respectively. 
Regarding the standards for design used in this work with steel bars (NBR 6118) or GFRP bars (ACI 440.1R-15), it can be said that the different guidelines did not lead to significant differences in terms of the beams' resistant capacity. When comparing the maximum loads of beams reinforced with steel and with GFRP, ratios of $+9.3 \%,-3.2 \%$, and $-3 \%$ were obtained, for beams designed for $23.5 \mathrm{kN}, 37.5 \mathrm{kN}$, and $57 \mathrm{kN}$, respectively. These results indicate good design practices in the two standards.

Also, the results suggest the beam designs had good levels of safety, with maximum load/design load ratios for beams VA23, VA37 and VA57 of 3.25, 3.36 and 2.52, respectively. For beams VV23, VV37 and VV57, the ratios were $2.97,3.47$ and 2.60 , respectively.

\section{ACKNOWLEDGEMENTS}

The authors would like to thank the company STRATUS Compostos Estruturais Ltda. for donating the GFRP bars, and the Laboratory of Materials and Construction Techniques (LabMat) of the Federal University of Pelotas for making space and equipment available for the tests.

\section{REFERENCES}

[1] D. H. Tavares, "Análise teórica e experimental de vigas de concreto armadas com barras não metálicas de GFRP,” M.S. thesis, Dept. Eng. Estrut., Univ. São Paulo, 2006.

[2] M. H. F. Medeiros and P. R. L. Helene, Durabilidade e Proteção do Concreto Armado. São Paulo: Téchne, 2009.

[3] F. L. Bolina, B. F. Tutikian, and P. R. L. Helene, Patologia de Estruturas. São Paulo: Oficina de Textos, 2019.

[4] F. Pereira and P. R. L. Helene, "Guía para el diagnóstico y la intervención correctiva," in Rehabilitación y Mantenimiento de Estructuras de Concreto. Bogotá: SIKA, 2007.

[5] X. Zhao, X. J. He, and Y. C. Yang, "Numerical simulation of GFRP reinforced concrete beams," Adv. Mater. Sci. Eng., vol. 2017, pp. $1-10,2017$.

[6] American Concrete Institute, State-of-the-Art Report on Fiber Reinforced Plastic (FRP) Reinforcement for Concrete Structures, ACI 440R-96, 2002.

[7] J. R. Correia, J. Ferreira, and F. Branco, "Utilização de perfis pultrudidos de fibra de vidro (GFRP) na construção," in $A n .2^{\circ}$ Congr. Nac. Constr. - Repensar a Construção, 2004.

[8] J. Farmer Junior, M. Aurich and R. Girardi, "Estudo comparativo entre vigas de concreto armado convencional e vigas armadas com barras de fibra de vidro," in An. 60 Congr. Bras. Conc., 2018.

[9] A. Landesmann, C. A. Seruti, and E. M. Batista, "Mechanical properties of glass fiber reinforced polymers members for structural applications," Mater. Res., vol. 18, no. 6, pp. 1372-1383, 2015.

[10] R. C. B. Silva, "Comportamento de vigas de concreto armadas com barras de CFRP e GFRP para infraestrutura de transportes," M.S. thesis, Inst. Mil. Eng., Rio de Janeiro, 2014.

[11] Associação Brasileira de Normas Técnicas, Projeto de Estruturas de Concreto - Procedimento, NBR 6118, 2014.

[12] American Concrete Institute, Guide for the Design and Construction of Concrete Reinforced with FRP Bars, ACI 440.1R-15, 2015.

[13] Associação Brasileira de Normas Técnicas, Agregados - Determinação da Composição Granulométrica, NBR NM $248,2003$.

[14] Associação Brasileira de Normas Técnicas, Agregado Graúdo - Determinação da Massa Específica, Massa Específica Aparente e Absorção de Água, NBR NM 53, 2009.

[15] Associação Brasileira de Normas Técnicas, Agregados - Determinação da Massa Unitária e Volume de Vazios, NBR NM $45,2006$.

[16] Associação Brasileira de Normas Técnicas, Agregado Miúdo - Determinação da Massa Específica Aparente e Absorção de Água, NBR NM 52, 2009.

Author contributions: TVF: conceptualization, obtaining the data, writing; ARP: conceptualization, methodology, supervision and CMP: conceptualization, methodology, supervision, formal analysis.

Editors: Ricardo Carrazedo, José Luiz Antunes de Oliveira e Sousa, Guilherme Aris Parsekian. 